\title{
Achievement of students' language proficiency and their attitudes toward TMM online
}

\author{
Rattana Jangpiboonpong ${ }^{\left.{ }^{*}\right)}$ \\ ${ }^{1}$ Foreign Languages Department, Faculty of International Studies, Prince of Songkla University \\ Phuket Campus, Phuket, Thailand \\ *) correspondence: rattana.ja@phuket.psu.ac.th
}

\begin{abstract}
This ongoing study is conducted to explore language proficiency and the attitudes of 63 first year students from Faculty of International Studies who use Tell Me More Online (TMM online) as their learning tool (Academic Year 1/2020) and the effectiveness of TMM Online in enhancing students' English language proficiency. The evaluation results from all English courses which the students registered in the semester will be used as a research instrument to see the student progress in English language learning or their language proficiency. Questionnaires and the semi-structured interview will be also launched to acquire the attitudes of the students towards doing self-learning exercises from TMM online. The results for the first phrase of data analysis was to see the attitude towards TMM online. It was revealed that the students' satisfaction on content, materials used, and application of TMM Online was at the satisfied level.
\end{abstract}

Keywords: achievement; language proficiency; attitudes

\section{INTRODUCTION}

It is very important for the university students to increase their levels of language proficiency especially the students who study in an international program. They need to use language for studying in classes and also their graduation condition or exit examination. Self-learning lessons are one of the effective methods to help the students achieve the goals and the expected learning outcomes. Moreover, there are several language self-learning programs which have been selected by the universities and use as the tools to enhance and improve students' language proficiency. Tell Me More Online (TMM), language learning software is one of the choices for Prince of Songkla University which has contributed to five campuses in Pattani, Had Yai, Surat Thani, Phuket, and Trang.

Therefore, it is important to look back to the effectiveness of asynchronous programs which the university use to evaluate the students' language proficiency and get them ready to be graduated. It is also needed to see the attitudes of the program users because listening to students' own voices is the first step to develop and obtain an effective instructional programs (CSIZÉR, K., KORMOS, J., \& SARKADI, Á., 2010). It can also help develop students' language skills to lead them to the success of studying in the university.

So that, this study is conducted to acquire the attitudes of the students towards doing selflearning exercises from TMM online. The study is also focused to explore and analyze students' English language proficiency.

The expectation of this study is to contribute its results to the area of English language learning in order to find the appropriate language teaching and learning strategies to assist the students to enhance and develop language skills. Furthermore, students' suggestions or their opinions for selecting good online self-learning software also take the important role to develop their language proficiency. 


\section{METHODS}

This ongoing research is conducted and collected the data from 63 undergraduate students who are freshmen. All of them were admitted to study in the International Business: China (IBC) Program in Academic Year 2020. The study is separated into phrases to investigate the data of students' attitudes towards doing self-learning exercises from TMM online and their achievement of language proficiency. This study is a kind of quantitative research mixed with qualitative one. The location of conducting and collecting research data is Faculty of International Studies (FIS), Prince of Songkla University, Phket Campus (PSU Phuket). The university is located on Andaman coast in the southern region of Thailand. Questionnaire focused on attitudes towards doing self-learning exercises from TMM online was launched during the first semester Academic Year 2020, and semi-structure interview was used to acquire their opinions about the software for language learning. Furthermore, language proficiency and class evaluation results from English courses which the students registered will be analyzed to see their achievement and the effects of TMM online on English language learning. That will be after the final examination period, around the mid of December 2020. The descriptive statistics, distribution or percentages were used to analyze the data which is collected from the participants. Five-Point Likert rating scale interpretation is also used to generate the students' satisfactions or attitudes towards TMM Online.

\section{RESULTS AND DISCUSSION}

The subjects of this study are 63 first year students who are majoring in International Business: China. Most subjects are females (79.40\%). They are all studying in the Faculty of International Studies, Prince of Songkla University, Phuket Campus. All of them enroll the English language courses in the first semester of Academic Year 2020.

TABLE 1. Level of Education started to Learn English

\begin{tabular}{lcc}
\hline $\begin{array}{c}\text { Level of Education started } \\
\text { to Learn English }\end{array}$ & Numbers of Students & Percentage \\
\hline 1. Pre- kindergarten & 8 & $12.70 \%$ \\
2. Kindergarten & 42 & $66.70 \%$ \\
3. Primary & 8 & $12.70 \%$ \\
4. Secondary & 5 & $7.90 \%$ \\
\hline
\end{tabular}

As shown in table 1, most of the students started to learn English at the kindergarten level, with the highest percentage (66.70). There were only 5 of them who began to learn English at secondary level, which is the least number (7.90\%).

TABLE 2. Length of time for studying English

\begin{tabular}{|c|c|c|}
\hline Length of time (year) & Numbers of Students & Percentage \\
\hline $1.1-5$ & 2 & $3.17 \%$ \\
\hline 2. $6-10$ & 7 & $11.11 \%$ \\
\hline 3. $11-15$ & 36 & $57.14 \%$ \\
\hline 4. $16-20$ & 18 & $28.53 \%$ \\
\hline
\end{tabular}

From table 2, most students (57.14\%) spent 11-15 years to learn English, and some of them (28.53\%) took only 11-15 years with this language. However, few students have 1-5 years to get familiar with English. 
TABLE 3. English courses students enrolled in Semester 1 Academic 2020

\begin{tabular}{lcc}
\hline \multicolumn{1}{c}{ Courses } & Numbers of Students & Percentages \\
\hline English for Fundamental Listening and Speaking & 36 & 57.10 \\
English for Fundamental Reading and Writing & 55 & 87.30 \\
English for Intermediate Listening and Speaking & 16 & 25.40 \\
English for Intermediate Reading and Writing & 5 & 7.90 \\
English for Advanced Listening and Speaking & 12 & 19.00 \\
English for Advanced Reading and Writing & 2 & 3.20 \\
\hline
\end{tabular}

The information from the table 3 indicated that most of them need to register for English Fundamental Reading and Writing and English Fundamental Listening and Speaking which was based on TOEIC Mock Test or the real TOEIC test results they have got before the first semester started. The numbers of students are 55 and 36 respectively. (Note: Students are required to register for two English courses focused on four skills; listening, speaking, reading and writing.)

TABLE 4. Attitude towards doing self-study using TMM Online focused on content and materials

\begin{tabular}{lcc}
\hline I am satisfied with TMM Online because... & $\bar{X}$ & S.D \\
\hline 1. the content on TMM Online is interesting and attractive. & 3.30 & .994 \\
2. the content is useful. & 3.84 & .766 \\
3. the lessons were designed in accordance with the content in the English courses I enrolled & 3.65 & .845 \\
4. the content in each lesson is easy to understand. & 3.73 & .846 \\
5. teaching aids and activities of each lesson are interesting. & 3.40 & .959 \\
\end{tabular}

The data collected and shown on the table 4 can indicate that the content and materials used in Tell Me More Online were appropriate and satisfied the students. The average scores of most questions were higher than 3.50. However, the satisfaction on how interesting or attractive the content is, being at a moderate level.

TABLE 5. Attitude towards doing self-study using TMM Online focused on knowledge application

\begin{tabular}{lcc}
\hline I am satisfied with TMM Online because... & $\bar{X}$ & S.D \\
\hline 1. I can develop my English language skills & 3.63 & .885 \\
2. the content can be applied to use in my daily life. & 3.65 & .845 \\
3. the content learnt from TMM online help me get more understanding of the English & 3.87 & .823 \\
lessons in my class. & 3.44 & .996 \\
4. doing self-learning exercises helps develop my English language skills more than & & \\
studying in classes. & 3.51 & 1.076 \\
5. learning from an asynchronous program is very important for me, and I can be & 3.40 & 1.040 \\
succeeded in my study. & 3.56 & .980 \\
6. I gain more self confidence in using English language. & \\
7. it can help me in studying other courses which English is used as a main language for \\
teaching and learning activities.
\end{tabular}

The data collected and shown on the table 5 can indicate that the students believed that they could apply knowledge gained from doing the self- learning exercises in Tell Me More Online. The average scores of most questions were higher than 3.50. However, the satisfaction on self-confidence development and the benefits of doing self-study via TMM Online, being at a moderate level.

\section{Students' suggestions on selecting a self-learning program or a good online learning software.}

The suggestions from the students are as follows;

1. Essay writing lessons should be provided to assist the students who take an advanced course.

2. The software should be innovated with iOS system support.

3. The content such as vocabulary list need to be updated.

4. It is necessary to make the program easy to access. 
5. Mobile applications on iOS and android system should be innovated for users' convenience

6. Interesting and attractive features should be provided on system

As we know that an asynchronous program is one of the Computer-assisted language learning (CALL) which can benefit the students who would like to enhance their language skills. For this study which is focused on students' attitudes towards doing self-study using TMM Online focused on content, materials, and its application.

The research results revealed that the students realize the usefulness of spending their valuable time to finish self-learning exercises on TMM Online. The students also taught that it was not too difficult to complete the online exercises, so they came up with the positive attitudes. The findings confirm the study on EFL Learners' satisfaction with the online learning program, Tell Me More by George and Panida. (Gyamfi and Sukseemuang, 2018). George and Panida were also conducted the research on the attitudes topics towards TMM Online. The results are also in accordance with Rucheng (Li, 2012) whose study considered on practices and attitudes during autonomous online learning or CALL. Rucheng confirmed that CALL affected the students' English language ability.

Additionally, the self-learning lessons design on TMM online was consisted of interesting and attractive features. The video simulation or roleplaying which were recorded by the native speakers are provided to encourage, motivate and enhance the students' language skills. The exercises were provided in the appropriate series form the basic to the advanced level which were relied on the learners' ability or their background.

According to the results of attitude towards doing self-study using TMM Online focused on knowledge application, it can be indicated that the students may not waste time to do selflearning lessons on TMM Online. That is because they could apply the things they have learned from the software to the learning strategies for the English courses they registered. Another important consideration, the students referred that they can apply the content they learned to their daily life because the lessons from this program were designed and stimulated from the real situations. From all reasons mentions may lead to the development of students' language proficiency.

\section{CONCLUSION}

In conclusion, it can be indicated that using self-learning program is still useful for the students who enroll to study in an international program for a university level especially the ones who are majoring in International Business: China, FIS, PSU Phuket. As you can see from the analyzed data, the level of satisfaction or attitudes of the IBC students were in the satisfied and moderate level. Additionally, language proficiency or evaluation results from the English courses that the students registered will be proofed to see the influence of doing self-learning exercise on TMM Online.

\section{ACKNOWLEDGEMENTS}

I would like to thank the following people and organizations for helping with this research project: English Education Department, Faculty of Teacher Training and Education, University of Islam Malang for arranging the great conference and kind consideration of research acceptance. Research Unit of Faculty of International Studies, PSU Phuket for funding and support. I would particularly like to thank Napacha P., who guided and encouraged me to conduct this research, and all FIS First year students from IBC program for sharing their opinions, attitudes towards TMM Online selflearning, and some useful information

\section{REFERENCES}

Csizér, K., Kormos, J., \& Sarkadi, Á. (2010). The Dynamics of Language Learning Attitudes and Motivation: Lessons from an Interview Study of Dyslexic Language Learners. The Modern Language Journal, 94(3), 470-487. http://www.jstor.org/stable/40856179 
Gyamfi G. \&Sukseemuang P. (2018). EFL Learners' Satisfaction with the Online Learning Program, Tell Me More. Turkish Online Journal of Distance Education-TOJDE, 1 (13), 183-202. https:// files.eric.ed.gov/fulltext/EJ1165887.pdf

Likert R. (1932). A technique for the measurement of attitudes. Arch Psychology, 22(140), 55. https://legacy.voteview.com/pdf/Likert_1932.pdf

Li, R (2012). The Influence of Computer Applied Learning Environment on EFL or ESL Education. Theory and Practice in Language Studies, 2(1), 187-191. https://doi.org/10.4304/tpls.2.1.187191 